\title{
PENGARUH PEMBERIAN PUPUK CANTIK DAN PUPUK ORGANIK CAIR HORMONIK TERHADAP PERTUMBUHAN DAN HASIL TANAMAN TERONG UNGU (SOLANUM MELONGENA L.) VARIETAS YUVITA F1
}

\author{
Habibie $^{1}$ \\ ${ }^{1}$ Agroteknologi, Fakultas Pertanian, Universitas 17 Agustus 1945 Samarinda, Indonesia. \\ E-Mail: habibie378@gmail.com
}

\begin{abstract}
ABSTRAK
Pengaruh Pemberian Pupuk Cantik dan Pupuk Organik Cair Hormonik terhadap Pertumbuhan dan Hasil Tanaman Terong Ungu (Solanum melongen L.) Varietas Yuvita F1. Tujuan penelitian adalah untuk : (1) mengetahui pengaruh pemberian pupuk Organik Cantik dan Pupuk Organik Cair Hormonik beserta interaksinya terhadap pertumbuhan dan produksi Tanaman Terong Ungu Varietas Yuvita F1; (2) mengetahui dosis pupuk Organik Cantik dan konsentrasi POC Hormonik yang sesuai untuk tanaman terong.

Penelitian dilaksanakan dari bulan Mei 2018 sampai bulan September 2018, terhitung sejak dari persiapan media tanam hingga pengambilan data terakhir. Tempat penelitian di Jl. Teuku Umar, Samarinda, Kalimantan Timur.

Penelitian menggunakan Rancangan Acak Lengkap (RAL) dengan pola faktorial 4 x 4 yang diulang sebanyak tiga ulangan. Faktor pertama adalah dosis pupuk Cantik (K) yang terdiri atas empat taraf yaitu : tanpa pupuk Cantik (k0), $150 \mathrm{~kg} \mathrm{ha}^{-1}$ setara $150 \mathrm{~g} \mathrm{polibag}^{-1}(\mathrm{k} 1), 250 \mathrm{~kg} \mathrm{ha}^{-1}$ setara $250 \mathrm{~g} \mathrm{polibag}^{-1}(\mathrm{k} 2)$, dan $350 \mathrm{~kg} \mathrm{ha}^{-1}$ setara $350 \mathrm{~g}$ polibag $^{-1}(\mathrm{k} 3)$. Faktor kedua adalah konsentrasi POC Hormonik (P) yang terdiri atas empat taraf yaitu : tanpa POC Hormonik (p0), $1 \mathrm{ml}^{-1}$ air (p1), $2 \mathrm{ml}^{-1}$ air (p2), dan $3 \mathrm{ml} \mathrm{l}^{-1}$ air (p3).

Hasil penelitian menunjukkan bahwa : (1) perlakuan pemberian pupuk Cantik berpengaruh sangat nyata terhadap tinggi tanaman pada umur 15, 30, dan 45 hari setelah tanam, jumlah buah per tanaman dan berat satu buah, dan berpengaruh nyata terhadap diameter dan panjang buah. Perlakuan $350 \mathrm{~g} \mathrm{polibag}^{-1}$ menghasilkan hasil buah tanaman terong ungu yang paling baik (2) perlakuan pemberian POC Hormonik berpengaruh sangat nyata terhadap tinggi tanaman pada umur 15, 30, dan 45 hari setelah tanam serta jumlah buah per tanaman; berpengaruh nyata terhadap berat satu buah, tetapi berpengaruh tidak nyata terhadap diameter buah dan panjang buah. Perlakuan $3 \mathrm{ml} \mathrm{l}^{-1}$ air ${ }^{-}$menghasilkan hasil buah tanaman terong ungu yang paling baik; dan (3) interaksi antara pupuk Cantik dan POC Hormonik berpengaruh sangat nyata terhadap tinggi tanaman pada umur 30 dan 45 hari setelah tanam; berpengaruh nyata terhadap jumlah buah per tanaman, tetapi berpengaruh tidak nyata terhadap tinggi tanaman pada umur 15 hari setelah tanam, diameter buah, panjang buah, dan berat satu buah.
\end{abstract}

Kata kunci : Pertumbuhan, Pupuk cantik, Pupuk Organik Cair Hormonik, Tanaman Terong Ungu.

\begin{abstract}
Effect of Cantik Fertilizer and Hormonik Liquid Organic Fertilizer on the Growth and Yield of Egg plant (Solanum melongena L.) Yuvita F1 Variety. The research objective were to study the effect of Cantik fertilizer and Hormonik liquid organic fertilizer and its interaction on the growth and yield of eggplant and also to find the proper dosage of Cantik fertilizer and Hormonik liquid organic fertilizer concentration for obtaining the best growth and yield of eggplant.

The research used Completely Randomized Design (CRD) in $4 \times 4$ Factorial Experiment and three replications. The factor was the dosage of Cantik fertilizer $(K)$ consisting of 4 levels : no Cantik fertilizer application ( $(\mathrm{k} 0), 150 \mathrm{~g}_{\text {polybag }}{ }^{-1}(\mathrm{kl}), 250 \mathrm{~g} \mathrm{polybag}^{-1}(\mathrm{k} 2)$; and $350 \mathrm{~g} \mathrm{polybag}^{-1}(\mathrm{k} 3)$. The second factor was the concentration of Hormonik liquid organic fertilizer $(P)$ consisting 4 levels : no Hormonik application $(p 0), 1 \mathrm{ml} l^{-1}$ water ( $\left.p 1\right), 2 \mathrm{ml} \mathrm{l}^{-1}$ water (p2), and $3 \mathrm{ml}^{-1}$ water (p3).

The results showed that: (1) the Cantik fertilizer treatment affected significantly to very significantly on the plant lenght at age 15, 30 and 45 days after planting, number of fruit per plant, diameter of fruit, lenght of fruit, and weight of one fruit. The best production was produced at $350 \mathrm{~g}$ polybag $^{-1}(\mathrm{k} 3)$ treatment.; (2) the
\end{abstract}


Hormonik liquid organic fertilitzer treatment affected significantly to very significantly on the plant lenght at age 15, 30 and 45 days after planting, number of fruit per plant and weight of one fruit, but it did not significant on the diameter and lenght of fruit. The best production was produced at $3 \mathrm{ml} \mathrm{l}^{-1}$ water (p3) treatment; and (3) the interaction treatment between Cantik fertilizer and Hormonik liquid organic fertilizer affected significantly to very significantly on the plant lenght at age 30 and 45 after planting, and number of fruit per plant, but did not affect significantly on the plant lenght at age 15 after planting, diameter of fruit, lenght of fruit and weight of one fruit.

Key words : Cantik Fertilizer, Egg plant, Growth, Hormonik Liquid Organic Fertilizer.

\section{PENDAHULUAN}

Terong (Solanum melongena L) adalah tanaman asli daerah tropis. Tanaman ini awalnya berasal dari Benua Asia yaitu India dan Birma. Daerah penyebaran tanaman terong awalnya di beberapa Negara (Wilayah) antara lain di Karibia, Malaysia, Afrika Barat, Tengah, Afrika Timur, dan Amerika Selatan. Tanaman ini menyebar ke seluruh dunia, baik Negara-negara yang beriklim panas (tropis) maupun iklim sedang (subtropis). Pengembangan budidaya terong paling pesat di Asia Tenggara, salah satunya di Indonesia (Harizamry, 2007).

Terong juga mengandung banyak vitamin dan gizi yang tinggi, seperti vitamin B-kompleks, thiamin, pyridoxine, riboflavin, zat besi, phosphorus, manganese, dan potassium. Terong adalah salah satu sumber makanan yang sangat di kenal oleh semua lapisan masyarakat. Terong menjadi salah satu menu yang paling di minati berbaga di kalangan. Untuk membelinya pun tidak sulit karena tersedia di pasar-pasar maupun super market. Selain rasanya enak, Terong juga bisa di olah menjadi bermacam - macam menu masakan. Bahkan cara mengolahnya terbilang sangat mudah (Eriyandi, 2008).

Suhu yang paling cocok untuk tanaman terong adalah $22^{\circ} \mathrm{C}-30^{\circ} \mathrm{C}$ dengan perbedaan sedikit antara suhu siang dan malam. Tanaman ini tumbuh baik pada tanah-tanah lempung berpasir dengan drainase yang baik. Terong tidak terlalu memerlukan suhu tinggi selama pertumbuhannya, namun juga tahan terhadap curah hujan yang tinggi dan tanah tidak terlalu lembab. Sayuran ini termasuk tanaman yang sedikit tahan terhadap kadar garam yang tinggi.

Sebagai salah satu sayuran pribumi, terong hampir selalu ditemukan di pasar tani pasar tradisional dengan harga yang relatif murah. Akhir-akhir ini bisnis terong masih memberikan peluang pasar yang cukup baik terutama untuk memenuhi permintaan pasar dalam negeri. Terong Ungu merupakana varietas terong lokal yang belakangan ini telah berhasil menembus pasaran luar negeri.

Pasar dalam negeri adalah pasar potensial bagi pemasaran buah dan sayuran. Komoditas sayuran dan buah memang di arahkan untuk menggairahkan pasar dalam negeri. Tetapi pasar tentu saja memerlukan persediaan barang yang diperlukan, baik secara kuantitas maupun kualitas tertentu. Untuk itu diperlukan sebuah pola pembudidayaan yang baik dan benar agar persediaan barang tersebut memenuhi harapan banyak pihak terkait. Baik petani, tengkulak, pedagang, grosir, hingga konsumen pada umumnya (Eriyandi, 2008).

Keinginan untuk mendapat hasil yang lebih baik diperlukan budidaya yang baik pula. Budidaya yang baik di antaranya dengan menggunakan sistem pemupukan secara teratur, penyiraman yang teratur, serta pengendalian hama dan penyakit. Dengan demikian akan menghasilkan hasil panen yang baik sehingga dapat memenuhi kebutuhan pasar yang diharapkan (Eriyandi, 2008).

Dalam hal pemupukan, pemupukan berguna untuk mempercepat 
pembungaan, pemasakan buah, merangsang pertumbuhan, batang dan membantu proses metabolisme. Kekurangan pupuk mengakibatkan pembelahan sel dalam tanaman tertunda dan pertumbuhan akar menjadi terhambat, tanaman kekuningan, kematangan buah dan pembentukan biji tertunda, penyerbukan biji tidak baik serta kerdil (Musnandar, 2003).

Pupuk organik sangat bermanfaat bagi peningkatan produksi pertanian baik kualitas maupun kuantitas, mengurangi pencemaran lingkungan, dan meningkatkan kualitas lahan secari berkelanjutan. Dan dapat mencegah degradasi lahan. Sumber bahan untuk pupuk organik sangat beraneka ragam, dengan karekteristik fisik dan kandungan kimia yang sangat beragam sehingga pengaruh dari penggunaan pupuk organik terhadap lahan dan tanaman dapat bervariasi. Selain itu, peranannya cukup besar terhadap perbaikan sifat fisika, kimia, biologi tanah serta lingkungan. pupuk Organik yang ditambahkan ke dalam tanah akan mengalami beberapa kali fase perombakan oleh mikro organisme tanah untuk menjadi humus. Bahan Organik juga berperan sebagai sumber energi dan makanan mikroba tanah sehingga dapat meningkatkan aktivitas mikroba tersebut dalam penyediaan hara tanaman (Musnandar, 2003).

Salah satu jenis pupuk yang baik digunakan untuk meningkatkan pertumbuhan dan hasil tanaman adalah pupuk Cantik, pupuk tersebut mengandung unsur hara Nitrogen $(\mathrm{N})$ dan juga Kalsium (Ca). Disamping pemberian pupuk melalui akar, untuk memacu pertumbuhan dan perkembangan tanaman dapat pula dikombinasikan dengan pemberian pupuk melalui daun. Salah satu jenis pupuk organik cair (POC) adalah Hormonik. POC Hormonik mengandung unsur hara makro
$(\mathrm{N}, \mathrm{P}$, dan $\mathrm{K})$ dan unsur hara mikro $(\mathrm{Cu}$, $\mathrm{Zn}, \mathrm{B}, \mathrm{Co}, \mathrm{Fe}, \mathrm{Mo}$ ) serta dilengkapi dengan zat pengatur tumbuh Gibberelin, Sitokinin dan Auksin.

Berdasarkan uraian di atas, dilaksanakan penelitian tentang pengaruh pemberian pupuk Organik Cantik dan Pupuk Organik Cair Hormonik serta interaksinya terhadap pertumbuhan dan hasil tanam terong ungu. Tujuan penelitian adalah untuk mengetahui pengaruh pemberian pupuk Organik Cantik dan Pupuk Organik Cair Hormonik beserta interaksinya terhadap pertumbuhan dan produksi Tanaman Terong Ungu Varietas Yuvita F1. Untuk mengetahui dosis pupuk Organik Cantik dan konsentrasi POC Hormonik yang sesuai untk tanaman terong.

\section{METODA PENELITIAN}

\subsection{Tempat dan Waktu}

Penelitian dilaksanakan Jl. Teuku Umar, Samarinda, Kalimantan Timur. Pada bulan Mei-September 2018.

\subsection{Bahan dan Alat}

Bahan yang digunakan adalah benih terong ungu varietas Yuvita F1, media tanamam berupa tanah lapisan atas tanah, pupuk Cantik, POC Hormonik, Furadan 3G, pestisida nabati, dan air sumur.

Peralatan yang digunakan adalah : cangkul untuk mengolah dan menggemburkan tanah, polibag ukuran 20 x $30 \mathrm{~cm}$, bak persemaian, timbangan analitik, kamera, lingga, meteran, laptop, printer, dan alat tulis lainnya.

\subsection{Rancangan Percobaan}

Penelitian ini menggunakan Rancangan Acak Lengkap (RAL) dengan pola faktorial 4 x 4 yang diulang sebanyak tiga ulangan. Faktor-faktor perlakuan terdiri atas : 
Faktor pertama adalah dosis pupuk Cantik (K) yang terdiri atas empat taraf yaitu :

$$
\begin{aligned}
& \mathrm{k} 0=\text { tanpa pupuk Cantik } \\
& \mathrm{k} 1=\text { dosis pupuk Cantik } 150 \mathrm{~kg} \mathrm{ha}^{-1} \text { setara } \\
& 1,5 \mathrm{~g} \text { polibag }^{-1} \\
& \mathrm{k} 2=\text { dosis pupuk Cantik } 250 \mathrm{~kg} \mathrm{ha}^{-1} \text { setara } \\
& 2,5 \text { g polibag }^{-1} \\
& \mathrm{k} 3=\text { dosis pupuk Cantik } 350 \mathrm{~kg} \mathrm{ha}^{-1} \text { setara } \\
& 3,5 \text { g polibag }^{-1}
\end{aligned}
$$

Faktor kedua adalah konsentrasi POC Hormonik (P) terdiri atas empat taraf yaitu :

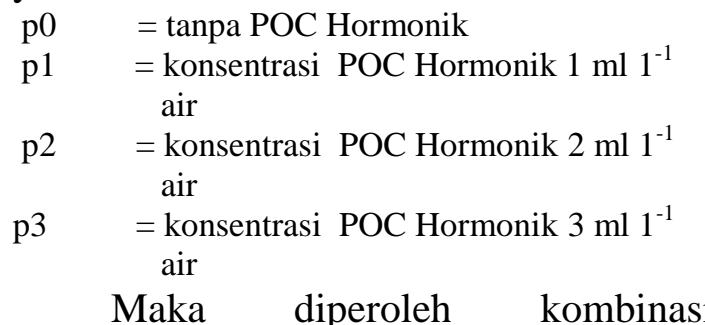

perlakuan 4 x 4 yaitu :

$\begin{array}{llll}\text { k0p0 } & \text { k0p1 } & \text { k0p2 } & \text { k0p3 } \\ \text { k1p0 } & \text { k1p1 } & \text { k1p2 } & \text { k1p3 } \\ \text { k2p0 } & \text { k2p1 } & \text { k2p2 } & \text { k2p3 } \\ \text { k3p0 } & \text { k3p1 } & \text { k3p2 } & \text { k3p }\end{array}$

\subsection{Pelaksanaan Penelitian}

Persiapan media tanam

Media yang digunakan dalam penelitian ini adalah tanah lapisan atas yang diambil di sekitar tempat penelitian, media tanah lapisan atas kemudian dibersihkan dari rumput dan diayak untuk memisahkan kotoran seperti ranting, akar, bekas plastik, dan lain sebagainya. Kemudian media tanam dimasukkan kedalam polibag sebanyak $20 \mathrm{~kg}$. Setelah media tanam dimasukkan kedalam polibag kemudian ditaburi Furadan 3G sebanyak $2 \mathrm{~g}$ polibag ${ }^{-1}$. Polibag-polibag tersebut diberi label sesuai perlakuan dan disusun rapi sesuai dengan hasil acak secara sederhana dengan undian, jarak antar polibag yaitu $60 \mathrm{~cm} \times 60 \mathrm{~cm}$.

\section{Persiapan benih}

Benih yang ditanam adalah varietas terong ungu varietas Yuvita F1. Sebelum benih ditanam, terlebih dahulu benih direndam dalam air hangat selama 15 menit, benih yang tenggelam adalah benih yang baik untuk dijadikan sebagai bahan tanam. Setelah itu benih ditabur ke media semai berupa baki yang berisi media tanam berupa tanah lapisan atas, lalu ditutup tipis dengan tanah. Bibit terong yang telah berumur 2 minggu setelah tabur (memiliki 2-4 helai daun) siap untuk dipindahkan ke polibag.

\section{Pemberian pupuk Cantik}

Pemberian pupuk Cantik ke dalam setiap polibag disesuaikan dengan dosis perlakuan, yaitu tanpa pupuk Cantik (k0), 1,5 $\mathrm{g} \mathrm{polibag}^{-1}(\mathrm{k} 1), 2,5 \mathrm{~g}_{\text {polibag }}{ }^{-1}(\mathrm{k} 2)$, dan 3,5 $\mathrm{g} \mathrm{polibag}^{-1}(\mathrm{k} 3)$. Pupuk Cantik diberikan 1 minggu sebelum tanam dengan cara menaburkan pada permukaan media tanam dalam polibag lalu diaduk secara merata dengan media tanam.

\section{Penanaman}

Penanaman dilakukan dengan cara membuat lubang tanam pada media tanam sedalam $5 \mathrm{~cm}$ dengan menggunakan telunjuk, lalu bibit dari persemaian ditanam sebanyak 1 bibit untuk setiap polibag, kemudian media tanam sekitar pangkal batang dipadatkan agar tanaman tidak roboh. Penanaman bibit dilakukan pada sore hari.

Pemberian POC Hormonik

Pemberian POC Hormonik pada setiap polibag disesuaikan dengan konsentrasi perlakuan, yaitu tanpa POC Hormonik (p0), $1 \mathrm{ml} \mathrm{l}^{-1}$ air (p1), $2 \mathrm{ml} \mathrm{l}^{-1}$ air (p2), dan $3 \mathrm{ml} \mathrm{l}^{-1}$ air (p3), Pemberian POC Hormonik diberikan sebanyak 5 tahap, yaitu pada saat tanaman berumur 10, 17, 24, 31 dan 45 hari setelah tanam. Pemberian POC Hormonik dilakukan pada pagi hari pukul 09,00 - 10,00 Wita dengan cara menyemprotkan larutan POC pada tubuh tanaman bagian atas terutama pada bagian daun sebelah bawah. 
Pemeliharaan

a). Penyiangan gulma

Penyiangan gulma dilakukan terhadap gulma yang tumbuh di dalam dan di luar polibag secara manual menggunakan tangan dan lingga.

b). Pengendalian hama dan penyakit

Apabila ada gejala serangan hama dan penyakit tanaman, dilakukan pengendalian dengan menggunakan pestisida nabati yang dibuat sendiri dengan bahan bawang putih, sabun cuci piring atau Sunligth, air, dan wadah untuk menyimpan. Cara pembuatan pestisida nabati yakni: siapkan bawang putih sebanyak 4 biji kemudian dihaluskan, setelah itu masukkan bahanbahan sebagai berikut kedalam media pengadukan yang berupa baskom yakni : 2 sendok shunlet, 1 liter air, dan bawang putih yang telah dihaluskan. Kemudian diaduk hingga merata. Setelah bahanbahan telah tercampur rata kemudian disaring dan dimasukkan kedalam media penyimpanan berupa botol bekas air mineral dan diamkan selama 1 x 24 jam. Pestisida nabati ini juga dianjurkan untuk tanaman yang terserang kutu putih atau kutu daun lainnya.

\section{Panen}

Ciri- ciri buah terong ungu yang siap panen mempunyai ciri- ciri : buah masih muda, umur 12-15 hari sejak bunga mekar, kulit buah berwarna ungu cerah atau cemerlang dan mengkilat. Pemanenan dilakukan dengan memetik buah menggunakan tangan, pemanenan dilakukan secara bertahap sesuai dengan tingkat kemasakan buah sebanyak 4 tahap dengan interval waktu panen 6 hari sekali.

\subsection{Pengambilan Data}

Data utama yang diambil dalam penelitian yaitu :

Tinggi tanaman $(\mathrm{cm})$
Tinggi tanaman terong ungu diamati pada umur 15, 30, dan 45 hari setelah tanam, dengan cara mengukur tanaman dari permukaan tanah yang diberi tanda sampai titik tumbuh tanaman pada batang utama/ primer.

Jumlah buah per tanaman

Jumlah buah per tanaman dihitung dengan cara menjumlahkan hasil buah panen 1 sampai panen ke 4 .

Diameter buah $(\mathrm{cm})$

Diameter buah terong diukur pada saat panen pada semua hasil panen, pengukuran dilakukan dengan cara mengukur bagian tengah buah terong, dengan menggunakan jangka sorong (Sigmat) kemudian dirata-ratakan.

Panjang buah $(\mathrm{cm})$

Panjang buah terong diukur pada saat panen pada semua buah, pengukuran dilakukan mulai dari pangkal buah dekat tangkai hingga ujung buah terong kemudian dirata-ratakan.

Berat satu buah $\left(\mathrm{g}_{\text {buah }}{ }^{-1}\right)$

Berat satu buah segar setiap tanaman dilakukan dengan cara menimbang berat buah tiap tanaman pada saat panen pertama hingga panen yang keempat kemudian dijumlahkan dan selanjutnya dibagi dengan jumlah buah.

\subsection{Analisis Data}

Untuk mengeetahui pengaruh pemberian pupuk Cantik dn POC Hormonik serta interaksinya terhadap pertumbuhan dan hasil tanaman terong ungu dilakukan dengan cara menganalisis data hasil penelitian dengan sidik ragam (Steel dan Torrie, 1991).

Bila hasil sidik ragam berpengaruh nyata (F hitung $>\mathrm{F}$ tabel $5 \%$ ) atau berpengaruh sangat nyata ( $\mathrm{F}$ hitung > 
F tabel $1 \%$ ), maka untuk membandingkan dua rata-rata perlakuan dilakukan uji lanjutan dengan uji beda nyata terkecil (BNT) taraf nyata $5 \%$ ), sedangkan bila

berpengauh tidak nyata ( $\mathrm{F}$ hitung $\leq \mathrm{F}$ tabel $5 \%$ ) maka tidak dilakukan uji lanjutan. Rumus umum uji BNT sebagai berikut :

$$
\text { BNT } 5 \%=\mathrm{t} \text { tabel } \mathrm{x} \sqrt{\frac{2 \text { KTgalat }}{r x t}}
$$

Keterangan :

$$
\begin{array}{ll}
\text { t-tabel } & =\text { nilai t pada tabel ( } 5 \% \text { dan nilai derajat bebas galat }) . \\
\mathrm{KT} \text { galat } & =\text { nilai kuadrat tengah galat. } \\
\mathrm{t} & =\text { jumlah perlakuan } \\
\mathrm{r} & =\text { jumlah ulangan }
\end{array}
$$

\section{HASIL PENELITIAN DAN PEMBAHASAN}

\subsection{Tinggi tanaman pada umur 15 hari setelah tanam}

Hasil sidik ragam menunjukkan bahwa perlakuan pupuk Cantik dan POC Hormonik berpengaruh sangat nyata, sedangkan interaksinya berpengaruh tidak nyata terhadap tinggi tanaman terong ungu pada umur 15 hari setelah tanam.

Hasil uji BNT taraf $5 \%$ pengaruh pupuk Cantik terhadap rata-rata tinggi tanaman pada umur 15 hari setelah tanam menunjukkan bahwa perlakuan 3,5 g polibag $^{-1} \quad(\mathrm{k} 3)$ berbeda nyata dibandingkan dengan perlakuan tanpa pupuk Cantik (k0), 1,5 $\mathrm{g}^{\text {polibag }}{ }^{-1}(\mathrm{k} 1)$ dan 2,5 $\mathrm{g}$ polibag $^{-1}(\mathrm{k} 2)$. Perlakuan 1,5 g polibag $^{-1}(\mathrm{k} 1)$ dan 2,5 $\mathrm{g}$ polibag $^{-1}(\mathrm{k} 2)$ berbeda tidak nyata dibandingkan dengan perlakuan tanpa pupuk Cantik (k0). Tanaman paling tinggi dihasilkan pada perlakuan 3,5 g polibag ${ }^{-1}(\mathrm{k} 3)$, yaitu $20.75 \mathrm{~cm}$, sedangkan yang paling rendah dihasilkan pada perlakuan tanpa pupuk Cantik (k0). yaitu $14,58 \mathrm{~cm}$.

Hasil uji BNT taraf $5 \%$ pengaruh POC Hormonik terhadap rata-rata tinggi tanaman pada umur 15 hari setelah tanam menunjukkan bahwa perlakuan $3 \mathrm{ml} \mathrm{l}^{-1}$ air (p3) berbeda nyata dibandingkan dengan perlakuan tanpa POC Hormonik (p0), tetapi berbeda tidak nyata dibandingkan dengan perlakuan $1 \mathrm{ml} \mathrm{l}^{-1}$ air (p1) dan $2 \mathrm{ml} \mathrm{l}^{-1}$ air (p2). Perlakuan 1 $\mathrm{ml} \mathrm{l}^{-1}$ air (p1) dan $2 \mathrm{ml} \mathrm{l}^{-1}$ air (p2) berbeda tidak nyata dibandingkan dengan perlakuan tanpa POC Hormonik (p0). Tanaman paling tinggi dihasilkan pada perlakuan $3 \mathrm{ml} \mathrm{l}^{-1}$ air (p3), yaitu 18,67 $\mathrm{cm}$, sedangkan yang paling rendah dihasilkan pada perlakuan tanpa POC Hormonik (p0), yaitu 14,67 cm.

\subsection{Tinggi tanaman pada umur 30 hari setelah tanam}

Hasil sidik ragam menunjukkan bahwa perlakuan pupuk Cantik dan POC Hormonik serta interaksinya berpengaruh sangat nyata terhadap tinggi tanaman terong ungu pada umur 30 hari setelah tanam.

Hasil uji BNT taraf $5 \%$ pengaruh pupuk Cantik terhadap rata-rata tinggi tanaman pada umur 30 hari setelah tanam menunjukkan bahwa perlakuan $2,5 \mathrm{~g}$ polibag $^{-1}$ (k2) dan 3,5 g polibag ${ }^{-1}(\mathrm{k} 3)$ berbeda nyata dibandingkan dengan perlakuan tanpa pupuk Cantik (k0) dan $1,5 \mathrm{~g}^{\text {polibag }}{ }^{-1}(\mathrm{k} 1)$, tetapi diantara kedua perlakuan ( $\mathrm{k} 2$ dan $\mathrm{k} 3$ ) tersebut berbeda tidak nyata. Perlakuan $1,5 \mathrm{~g}_{\text {polibag }}{ }^{-1}$ (k1) berbeda nyata dibandingkan dengan perlakuan tanpa pupuk Cantik (k0). Tanaman paling tinggi dihasilkan pada perlakuan 3,5 g polibag $^{-1}(\mathrm{k} 3)$, yaitu 
$30,58 \mathrm{~cm}$, sedangkan yang paling rendah dihasilkan pada perlakuan tanpa pupuk Cantik (k0). yaitu $20,58 \mathrm{~cm}$.

Hasil uji BNT taraf $5 \%$ pengaruh POC Hormonik terhadap rata-rata tinggi tanaman pada umur 30 hari setelah tanam menunjukkan bahwa perlakuan $2 \mathrm{ml} \mathrm{l}^{-1}$ air (p2) dan $3 \mathrm{ml} \mathrm{l}^{-1}$ air (p3) berbeda nyata dibandingkan dengan perlakuan tanpa POC Hormonik (p0) dan perlakuan $1 \mathrm{ml} \mathrm{l}^{-1}$ air (p1), tetapi diantara kedua perlakuan (p2 dan p3) tersebut berbeda tidak nyata. Perlakuan $1 \mathrm{ml} \mathrm{l}^{-1}$ air (p1) berbeda nyata dibandingkan dengan perlakuan tanpa POC Hormonik (p0). Tanaman paling tinggi dihasilkan pada perlakuan $3 \mathrm{ml} \mathrm{l}^{-1}$ air (p3), yaitu 31,67 $\mathrm{cm}$, sedangkan yang paling rendah dihasilkan pada perlakuan tanpa POC Hormonik (p0), yaitu 20,92 cm.

Hasil uji BNT taraf $5 \%$ pengaruh interaksi $\mathrm{K} \times \mathrm{P}$ terhadap rata-rata tinggi tanaman pada umur 30 hari setelah tanam menunjukkan bahwa kombinasi k3p3 berbeda nyata dibandingkan dengan kombinasi k0p0, k0p1, k0p2, k0p3, k1p0, k1p1, k2p0, k2p1, k3p0, dan k3p1, tetapi berbeda tidak nyata dibandingkan dengan kombinasi k1p2, k1p3, k2p2, k2p3, dan k3p2. Kombinasi k2p3 berbeda nyata dibandingkan dengan kombinasi k0p0, k0p1, k0p2, k0p3, k1p0, k1p1, k2p0, $\mathrm{k} 2 \mathrm{p} 1$, dan $\mathrm{k} 3 \mathrm{p} 0$, tetapi berbeda tidak nyata dibandingkan dengan kombinasi k1p2, k1p3, k2p2, k3p1, dan dan k3p2. Kombinasi k1p2, k1p3, k2p2 dan k3p2 berbeda nyata dibandingkan dengan kombinasi k0p0, k0p1, k0p2, k0p3, k1p0, $\mathrm{k} 1 \mathrm{p} 1$, k2p0, dan k3p0, tetapi berbeda tidak nyata dibandingkan dengan kombinasi k2p1, dan k3p1. Kombinasi $\mathrm{k} 2 \mathrm{p} 1$ dan $\mathrm{k} 3 \mathrm{p} 1$ berbeda nyata dibandingkan dengan kombinasi k0p0, k0p1, k0p2, k0p3, k1p0, k1p1, k2p0, dan $\mathrm{k} 3 \mathrm{p} 0$. Kombinasi k0p0 dan k1p1 berbeda nyata dibandingkan dengan kombinasi k0p3, tetapi berbeda tidak nyata dibandingkan dengan kombinasi k0p1, k0p2, k1p0, k2p0, dan k3p0. Kombinasi k0p1, k0p2, k1p0, k2p0, dan $\mathrm{k} 3 \mathrm{p} 0$ berbeda tidak nyata dibandingkan dengan kombinasi k0p3. tetapi berbeda tidak nyata dibandingkan dengan kombinasi k0p1, k0p2, k1p0, k2p0, dan $\mathrm{k} 3 \mathrm{p} 0$. Tanaman paling tinggi dihasilkan pada kombinasi $\mathrm{k} 3 \mathrm{p} 3$, yaitu $36,33 \mathrm{~cm}$, sedangkan yang paling rendah dihasilkan pada kombinasi k0p3, yaitu 19,33 cm.

\subsection{Tinggi tanaman pada umur 45 hari setelah tanam}

Hasil sidik ragam menunjukkan bahwa perlakuan pupuk Cantik dan POC Hormonik serta interaksinya berpengaruh sangat nyata terhadap tinggi tanaman terong pada umur 45 hari setelah tanam.

Hasil uji BNT taraf $5 \%$ pengaruh pupuk Cantik terhadap rata-rata tinggi tanaman pada umur 45 hari setelah tanam menunjukkan bahwa perlakuan $3,5 \mathrm{~g}$ polibag $^{-1} \quad(\mathrm{k} 3)$ berbeda nyata dibandingkan dengan perlakuan tanpa pupuk Cantik (k0), 1,5 $\mathrm{g}_{\text {polibag }}{ }^{-1}(\mathrm{k} 1)$ dan 2,5 $\mathrm{g}$ polibag ${ }^{-1}(\mathrm{k} 2)$. Perlakuan 1,5 g polibag $^{-1}(\mathrm{k} 1)$ dan 2,5 $\mathrm{g}^{\text {polibag }}{ }^{-1}(\mathrm{k} 2)$ berbeda nyata dibandingkan dengan perlakuan tanpa pupuk Cantik (k0). Tanaman paling tinggi dihasilkan pada perlakuan 3,5 $\mathrm{g}^{\text {polibag }^{-1}}(\mathrm{k} 3)$, yaitu $40,25 \mathrm{~cm}$, sedangkan yang paling rendah dihasilkan pada perlakuan tanpa pupuk Cantik (k0). yaitu 30,00 cm.

Hasil uji BNT taraf $5 \%$ pengaruh POC Hormonik terhadap rata-rata tinggi tanaman pada umur 45 hari setelah tanam menunjukkan bahwa perlakuan $1 \mathrm{ml} \mathrm{l}^{-1}$ air (p1), $2 \mathrm{ml} \mathrm{l}^{-1}$ air (p2) dan $3 \mathrm{ml} \mathrm{l}^{-1}$ air (p3) berbeda nyata dibandingkan dengan perlakuan tanpa POC Hormonik (p0), tetapi diantara ketiga perlakuan (p1, p2 dan p3) tersebut berbeda tidak nyata. Tanaman paling tinggi dihasilkan pada perlakuan $3 \mathrm{ml} \mathrm{l}^{-1}$ air (p3), yaitu 38,08 $\mathrm{cm}$, sedangkan yang paling rendah dihasilkan pada perlakuan tanpa POC Hormonik (p0), yaitu 29,08 cm. 
Hasil uji BNT taraf $5 \%$ pengaruh interaksi $\mathrm{K} \times \mathrm{P}$ terhadap rata-rata tinggi tanaman pada umur 45 hari setelah tanam menunjukkan bahwa kombinasi k3p3 berbeda nyata dibandingkan dengan kombinasi k0p0, k0p1, k0p2, k0p3, k1p0, k1p1, k1p2, k1p3, k2p0, k2p1, k2p3, dan $\mathrm{k} 3 \mathrm{p} 0$, tetapi berbeda tidak nyata dibandingkan dengan kombinasi k2p2, k3p1, dan k3p2. Kombinasi k3p1 dan $\mathrm{k} 3 \mathrm{p} 2$ berbeda nyata dibandingkan dengan kombinasi k0p0, k0p1, k0p2, k0p3, k1p0, k1p1, k1p2, k1p3, k2p0, $\mathrm{k} 2 \mathrm{p} 1$, k2p3, dan $\mathrm{k} 3 \mathrm{p} 0$, tetapi berbeda tidak nyata dibandingkan dengan kombinasi k2p2. Kombinasi k2p2 berbeda nyata dibandingkan dengan kombinasi k0p0, k0p1, k0p2, k0p3, k1p0, $\mathrm{k} 1 \mathrm{p} 1, \mathrm{k} 1 \mathrm{p} 2, \mathrm{k} 2 \mathrm{p} 0, \mathrm{k} 2 \mathrm{p} 1$, dan k3p0, tetapi berbeda tidak nyata dibandingkan dengan kombinasi k1p3 dan k2p3. Kombinasi k2p3 berbeda nyata dibandingkan dengan kombinasi k0p0, k0p1, k1p0, dan $\mathrm{k} 3 \mathrm{p} 0$, tetapi berbeda tidak nyata dibandingkan dengan kombinasi k0p2, k0p3, k1p0, k1p1, k1p2, k2p0, dan k2p1. Kombinasi k1p1 berbeda nyata dibandingkan dengan kombinasi k0p0, dan $\mathrm{k} 3 \mathrm{p} 0$, tetapi berbeda tidak nyata dibandingkan dengan kombinasi k0p1, k0p2, k0p3, k1p0, k1p2, k2p0, k2p1, dan k2p1. Kombinasi k0p1, k0p2, k0p3, k1p0, k1p2, k2p0, k2p1, dan k2p1 berbeda nyata dibandingkan dengan kombinasi $\mathrm{k} 0 \mathrm{p} 0 \mathrm{k} 3 \mathrm{p} 0$, tetapi berbeda tidak nyata dibandingkan dengan kombinasi k3p0. Kombinasi k3p0 berbeda tidak nyata dibandingkan dengan kombinasi k0p0. Tanaman paling tinggi dihasilkan pada kombinasi k3p3, yaitu $46,33 \mathrm{~cm}$, sedangkan yang paling rendah dihasilkan pada kombinasi k0p0, yaitu $22,00 \mathrm{~cm}$.

\subsection{Jumlah Buah per Tanaman}

Hasil sidik ragam menunjukkan bahwa perlakuan pupuk Cantik dan POC Hormonik berpengaruh sangat nyata; dan interaksinya berpengaruh nyata terhadap jumlah buah per tanaman terong ungu.

Hasil uji BNT taraf $5 \%$ pengaruh pupuk Cantik terhadap rata-rata jumlah buah per tanaman menunjukkan bahwa perlakuan 1,5 $\mathrm{g}_{\text {polibag }}{ }^{-1}(\mathrm{k} 1), \quad 2,5 \mathrm{~g}$ polibag $^{-1}(\mathrm{k} 2)$ dan 3,5 g polibag ${ }^{-1}(\mathrm{k} 3)$ berbeda nyata dibandingkan dengan perlakuan tanpa pupuk Cantik (k0), dan diantara ketiga perlakuan (k1, k2, dan k3) tersebut juga berbeda nyata. Jumlah buah per tanaman paling banyak dihasilkan pada perlakuan 3,5 g polibag ${ }^{-1}(\mathrm{k} 3)$, yaitu 10,25 buah tanaman ${ }^{-1}$, sedangkan yang paling sedikit dihasilkan pada perlakuan tanpa pupuk Cantik (k0). yaitu 4,33 buah tanaman $^{-1}$.

Hasil uji BNT taraf $5 \%$ pengaruh POC Hormonik terhadap rata-rata ratarata jumlah buah per tanaman menunjukkan bahwa perlakuan $2 \mathrm{ml} \mathrm{l}^{-1}$ air (p2) dan $3 \mathrm{ml} \mathrm{l}^{-1}$ air (p3) berbeda nyata dibandingkan dengan perlakuan tanpa POC Hormonik (p0) dan $1 \mathrm{ml} \mathrm{l}^{-1}$ air (p1), tetapi diantara kedua perlakuan (p2 dan p3) tersebut berbeda tidak nyata. Perlakuan $1 \mathrm{ml} \mathrm{l}^{-1}$ air (p1) berbeda nyata dibandingkan dengan perlakuan tanpa POC Hormonik (p0), Jumlah buah per tanaman paling banyak dihasilkan pada perlakuan $2 \mathrm{ml} \mathrm{l}^{-1}$ air (p2) dan $3 \mathrm{ml} \mathrm{l}^{-1}$ air (p3), yaitu 7,75 buah tanaman ${ }^{-1}$, sedangkan yang paling sedikit dihasilkan pada perlakuan tanpa POC Hormonik (p0), yaitu 6,00 buah tanaman ${ }^{-1}$.

Hasil uji BNT taraf $5 \%$ pengaruh interaksi $\mathrm{K}$ x P terhadap rata-rata jumlah buah per tanaman menunjukkan bahwa kombinasi k3p3 berbeda nyata dibandingkan dengan kombinasi dibandingkan dengan kombinasi k0p0, k0p1，k0p2，k0p3，k1p0，k1p1，k1p2, k1p3, k2p0, k2p1, k2p2, k2p3, dan k3p0, tetapi berbeda tidak nyata dibandingkan dengan kombinasi k3p1 dan k3p2. Kombinasi k3p1 dan k3p2 berbeda nyata dibandingkan dengan kombinasi dibandingkan dengan kombinasi k0p0, 
k0p1，k0p2，k0p3，k1p0, k1p1，k1p2, $\mathrm{k} 1 \mathrm{p} 3, \mathrm{k} 2 \mathrm{p} 0, \mathrm{k} 2 \mathrm{p} 1, \mathrm{k} 2 \mathrm{p} 2$, dan k2p3, tetapi berbeda tidak nyata dibandingkan dengan kombinasi k3p0.

Kombinasi k3p0 berbeda nyata dibandingkan dengan kombinasi dibandingkan dengan kombinasi $\mathrm{k} 0 \mathrm{p} 0$, k0p1, k0p2, k0p3, k1p0, k1p1, k1p3, tetapi berbeda tidak nyata dibandingkan dengan kombinasi k1p2, k2p0, k2p1, k2p2, dan k2p3. Kombinasi k1p2, k2p2 dan $k 2 p 3$ berbeda nyata dibandingkan dengan kombinasi dibandingkan dengan kombinasi k0p0, k0p1, k0p2, k0p3, tetapi berbeda tidak nyata dibandingkan dengan kombinasi k1p0, k1p1, k1p3, k2p0 dan k2p1. Kombinasi k2p0 dan $\mathrm{k} 2 \mathrm{p} 1$ berbeda nyata dibandingkan dengan kombinasi dibandingkan dengan kombinasi k0p0 dan k0p1, tetapi berbeda tidak nyata dibandingkan dengan kombinasi k0p2, k0p3, k1p0, dan k1p3. Kombinasi k1p0 dan k1p3 berbeda nyata dibandingkan dengan kombinasi dibandingkan dengan kombinasi k0p0, tetapi berbeda tidak nyata dibandingkan dengan kombinasi k0p2 dan k0p3. Kombinasi k0p1, k0p2 dan k0p3 berbeda tidak nyata dibandingkan dengan kombinasi dibandingkan dengan kombinasi k0p0. Jumlah buah per tanaman paling banyak dihasilkan pada kombinasi k3p3 yaitu 11,67 buah tanaman $^{-1}$, sedangkan yang paling sedikit dihasilkan pada kombinasi k0p0 yaitu 3,00 buah tanaman ${ }^{-1}$.

\subsection{Diamater Buah}

Hasil sidik ragam menunjukkan bahwa perlakuan pupuk Cantik berpengaruh, sedangkan perlakuan POC Hormonik dan interaksinya berpengaruh tidak nyata terhadap diameter buah tanaman terong ungu.

Hasil uji BNT taraf $5 \%$ pengaruh pupuk Cantik terhadap rata-rata diameter buah menunjukkan bahwa perlakuan 2,5 $\mathrm{g}$ polibag $^{-1}(\mathrm{k} 2)$ dan 3,5 $\mathrm{g}$ polibag $^{-1}(\mathrm{k} 3)$ berbeda nyata dibandingkan dengan perlakuan tanpa pupuk Cantik (k0), tetapi berbeda tidak nyata dibandingkan dengan perlakuan 1,5 $\mathrm{g}_{\text {polibag }^{-1}}(\mathrm{k} 1)$ dan diantara kedua perlakuan ( $\mathrm{k} 2$ dan $\mathrm{k} 3$ ) tersebut juga berbeda nyata. Perlakuan 1,5 g polibag $^{-1}(\mathrm{k} 1)$ berbeda tidak nyata dibandingkan dengan perlakuan tanpa pupuk Cantik (k0). Diameter buah paling besar dihasilkan padetapi a perlakuan 3,5 g polibag $^{-1}(\mathrm{k} 3)$, yaitu $17,00 \mathrm{~cm}$, sedangkan yang paling kecil dihasilkan pada perlakuan tanpa pupuk Cantik (k0). yaitu $12,00 \mathrm{~cm}$.

\subsection{Panjang Buah}

Hasil sidik ragam menunjukkan bahwa perlakuan pupuk Cantik berpengaruh, sedangkan perlakuan POC Hormonik dan interaksinya berpengaruh tidak nyata terhadap panjang buah tanaman terong ungu.

Hasil uji BNT taraf $5 \%$ pengaruh pupuk Cantik terhadap rata-rata panjang buah menunjukkan bahwa perlakuan 3,5 g polibag $^{-1}(\mathrm{k} 3)$ berbeda nyata dibandingkan dengan perlakuan tanpa pupuk Cantik (k0), tetapi berbeda tidak nyata dibandingkan dengan perlakuan 1,5 $\mathrm{g}$ polibag $^{-1}(\mathrm{k} 1)$ dan 2,5 $\mathrm{g}_{\text {polibag }}{ }^{-1}(\mathrm{k} 2)$. Perlakuan 1,5 $\mathrm{g}$ polibag $^{-1}(\mathrm{k} 1)$ dan $2,5 \mathrm{~g}$ polibag $^{-1}(\mathrm{k} 2)$ dan berbeda tidak nyata dibandingkan dengan perlakuan tanpa pupuk Cantik (k0). Panjang buah paling panjang dihasilkan pada perlakuan $3,5 \mathrm{~g}$ polibag $^{-1}(\mathrm{k} 3)$, yaitu $21,25 \mathrm{~cm}$, sedangkan yang paling pendek dihasilkan pada perlakuan tanpa pupuk Cantik (k0). yaitu $11,58 \mathrm{~cm}$.

\subsection{Berat Satu Buah}

Hasil sidik ragam menunjukkan bahwa perlakuan pupuk Cantik berpengaruh sangat nyata, perlakuan POC Hormonik berpengaruh nyata, sedangkan interaksinya berpengaruh tidak nyata terhadap berat satu buah tanaman terong ungu. 
Hasil uji BNT taraf $5 \%$ pengaruh pupuk Cantik terhadap rata-rata berat satu buah menunjukkan bahwa perlakuan 3,5 g polibag ${ }^{-1}(\mathrm{k} 3)$ berbeda nyata dibandingkan dengan perlakuan tanpa pupuk Cantik (k0), 1,5 g polibag ${ }^{-1}(\mathrm{k} 1)$ dan 2,5 g polibag $^{-1}(\mathrm{k} 2)$. Perlakuan 2,5 $\mathrm{g}$ polibag $^{-1}(\mathrm{k} 2)$ berbeda nyata dibandingkan dengan perlakuan tanpa pupuk Cantik (k0), tetapi berbeda tidak nyata dibandingkan dengan perlakuan 1,5 $\mathrm{g} \mathrm{polibag}^{-1}(\mathrm{k} 1)$. Perlakuan 1,5 $\mathrm{g}$ polibag $^{-1}$ (k1) berbeda tidak nyata dibandingkan dengan perlakuan tanpa pupuk Cantik (k0). Berat satu buah paling besar dihasilkan pada perlakuan 3,5 $\mathrm{g}$ polibag $^{-1}$ (k3), yaitu 179,58 g buah ${ }^{-1}$, sedangkan yang paling rendah dihasilkan pada perlakuan tanpa pupuk Cantik (k0). yaitu $110,00 \mathrm{~g} \mathrm{buah}^{-1}$.

Hasil uji BNT taraf $5 \%$ pengaruh

POC Hormonik terhadap rata-rata berat satu buah menunjukkan bahwa perlakuan $3 \mathrm{ml} \mathrm{l}^{-1}$ air (p3) berbeda nyata dibandingkan dengan perlakuan $1 \mathrm{ml} \mathrm{l}^{-1}$ air (p1), tetapi berbeda tidak nyata dibandingkan dengan perlakuan tanpa POC Hormonik dan perlakuan $2 \mathrm{ml} \mathrm{l}^{-1}$ air (p2). Perlakuan $1 \mathrm{ml} \mathrm{l}^{-1}$ air (p1) dan 2 $\mathrm{ml} \mathrm{l}^{-1}$ air (p1) berbeda tidak nyata dibandingkan dengan perlakuan tanpa POC Hormonik (p0). Berat satu buah paling besar dihasilkan pada perlakuan 3 $\mathrm{ml} \mathrm{l}^{-1}$ air (p3), yaitu $154,17 \mathrm{~g}$ buah ${ }^{-1}$, sedangkan yang paling rendah dihasilkan pada perlakuan $1 \mathrm{ml} \mathrm{l}^{-1}$ air (p1), yaitu $128,75 \mathrm{~g} \mathrm{buah}^{-1}$.

Rekapitulasi hasil penelitian pengaruh pemberian pupuk Cantik dan pupuk organik cair Hormonik terhadap pertumbuhan dan hasil tanaman terong ungu varietas Yuvita F1 disajikan pada Tabel 1. 
Tabel 1. Rekapitulasi Hasil Penelitian Pengaruh Pemberian Pupuk Cantik dan Pupuk Organik Cair Hormonik serta Interaksinya terhadap Pertumbuhan dan Hasil Tanaman Terong Ungu Varietas Yuvita F1

\begin{tabular}{|c|c|c|c|c|c|c|c|}
\hline \multirow{2}{*}{$\begin{array}{l}\text { Faktor-Faktor } \\
\text { Perlakuan }\end{array}$} & \multicolumn{3}{|c|}{ Tinggi Tanaman cm) } & \multirow{2}{*}{$\begin{array}{c}\text { Jumlah buah } \\
\text { pertanaman } \\
\text { (buah) }\end{array}$} & \multirow{2}{*}{$\begin{array}{c}\text { Diameter } \\
\text { Buah (cm) }\end{array}$} & \multirow{2}{*}{$\begin{array}{c}\text { Panjang } \\
\text { Buah (cm) }\end{array}$} & \multirow{2}{*}{$\begin{array}{c}\text { Berat } \\
\text { Satu } \\
\text { Buah }(\mathrm{g})\end{array}$} \\
\hline & 15 HST & 30 HST & 45 HST & & & & \\
\hline $\begin{array}{l}\text { Perlakuan Pupuk } \\
\text { Cantik (K) }\end{array}$ & $* *$ & $* *$ & $* *$ & $* *$ & $* *$ & $* *$ & $* *$ \\
\hline $\begin{array}{lll}\text { Tanpa } & \text { Pupuk } & \text { Cantik } \\
\text { (k0) } & & \end{array}$ & $14,58 \mathrm{c}$ & $20,58 \mathrm{c}$ & $30,00 \mathrm{c}$ & $4,33 \mathrm{~d}$ & $12,00 \mathrm{~b}$ & $11.58 \mathrm{~b}$ & $110,00 \mathrm{c}$ \\
\hline 1,5 g polibag $^{-1}(\mathrm{k} 1)$ & $15,00 \mathrm{c}$ & $27,83 \mathrm{~b}$ & $33,67 \mathrm{~b}$ & $6,63 \mathrm{c}$ & $13,42 \mathrm{ab}$ & $15,58 \mathrm{ab}$ & $119,17 \mathrm{c}$ \\
\hline $2,5 \mathrm{~g} \mathrm{polibag}^{-1}(\mathrm{k} 2)$ & $16,58 \mathrm{~b}$ & $30,42 \mathrm{a}$ & $36,00 \mathrm{~b}$ & $7,33 \mathrm{~b}$ & $16,08 \mathrm{a}$ & $17.94 \mathrm{ab}$ & $153,25 \mathrm{~b}$ \\
\hline 3,5 g ploibag $^{-1}(\mathrm{k} 3)$ & $20,75 \mathrm{a}$ & $30,58 \mathrm{a}$ & $40,25 \mathrm{a}$ & $10,25 \mathrm{a}$ & $17,00 \mathrm{a}$ & $21,25 \mathrm{a}$ & $179,58 \mathrm{a}$ \\
\hline $\begin{array}{l}\text { Perlakuan POC } \\
\text { Hormonik (P) }\end{array}$ & $*$ & $* *$ & $* *$ & $*$ & tn & tn & $*$ \\
\hline $\begin{array}{l}\text { Tanpa POC Hormonik } \\
(\mathrm{p} 0)\end{array}$ & $14,67 \mathrm{~b}$ & $20,92 \mathrm{c}$ & $29,08 \mathrm{~b}$ & $6,00 \mathrm{c}$ & 13,92 & 14.90 & $137,50 \mathrm{ab}$ \\
\hline $1 \mathrm{ml} \mathrm{l}^{-1}$ air $(\mathrm{p} 1)$ & $16,29 \mathrm{a}$ & $26,83 \mathrm{~b}$ & $35,17 \mathrm{a}$ & $6,90 \mathrm{~b}$ & 14,08 & 16.33 & $128,75 \mathrm{~b}$ \\
\hline $2 \mathrm{ml} \mathrm{l}^{-1}$ air (p2) & $17,29 \mathrm{a}$ & $30,00 \mathrm{a}$ & $37,58 \mathrm{a}$ & $7,75 \mathrm{a}$ & 15,33 & 17.25 & $141,58 \mathrm{ab}$ \\
\hline $3 \mathrm{ml} \mathrm{l}^{-1}$ air $(\mathrm{p} 3)$ & $18,67 \mathrm{a}$ & $31,67 \mathrm{a}$ & $38,08 \mathrm{a}$ & $7,75 \mathrm{a}$ & 15,17 & 17.87 & $154,17 \mathrm{a}$ \\
\hline Interaksi (K x P) & tn & $* *$ & $* *$ & $*$ & tn & $\operatorname{tn}$ & tn \\
\hline k0p0 & 10,67 & $23,00 \mathrm{~d}$ & $22,00 \mathrm{~g}$ & $3,00 \mathrm{~g}$ & 12,00 & 10.00 & 103,33 \\
\hline $\mathrm{k} 0 \mathrm{p} 1$ & 17,00 & $20,00 \mathrm{de}$ & 30,00 ef & $4,33 \mathrm{fg}$ & 11,67 & 11,33 & 103,33 \\
\hline $\mathrm{k} 0 \mathrm{p} 2$ & 16,67 & $20,00 \mathrm{de}$ & $34,67 \mathrm{def}$ & $5,00 \mathrm{efg}$ & 13,33 & 12,00 & 110,00 \\
\hline $\mathrm{k} 0 \mathrm{p} 3$ & 14,00 & $19,33 \mathrm{e}$ & $33,33 \mathrm{de}$ & 5,00 efg & 11,00 & 13,00 & 123,33 \\
\hline k1p0 & 14,33 & $20,00 \mathrm{de}$ & $33,33 \mathrm{de}$ & $6,00 \mathrm{def}$ & 11,33 & 13,50 & 146,67 \\
\hline $\mathrm{k} 1 \mathrm{p} 1$ & 12,17 & $23,00 \mathrm{~d}$ & 35,33 cde & 6,00 def & 13,00 & 15,33 & 100,00 \\
\hline $\mathrm{k} 1 \mathrm{p} 2$ & 15,17 & $33,00 \mathrm{abc}$ & 31,67 ef & $7,67 \mathrm{~cd}$ & 14,00 & 17,00 & 106,67 \\
\hline $\mathrm{k} 1 \mathrm{p} 3$ & 18,33 & $35,33 \mathrm{abc}$ & 34,33 cdef & $8,00 \mathrm{~cd}$ & 15,33 & 16,47 & 123,33 \\
\hline $\mathrm{k} 2 \mathrm{p} 0$ & 15,00 & $20,00 \mathrm{de}$ & 32,67 def & 6,67 cde & 16,33 & 15,57 & 130,00 \\
\hline $\mathrm{k} 2 \mathrm{p} 1$ & 16,33 & $32,00 \mathrm{c}$ & $33,00 \mathrm{def}$ & 7,00 cde & 14,67 & 18,00 & 143,33 \\
\hline $\mathrm{k} 2 \mathrm{p} 2$ & 17,00 & $34,00 \mathrm{abc}$ & $40,00 \mathrm{abc}$ & $7,67 \mathrm{~cd}$ & 16,67 & 18,67 & 166,33 \\
\hline $\mathrm{k} 2 \mathrm{p} 3$ & 18,00 & $35,67 \mathrm{ab}$ & 38,33 bcd & $8,00 \mathrm{~cd}$ & 16,67 & 19,33 & 173,33 \\
\hline $\mathrm{k} 3 \mathrm{p} 0$ & 18,67 & $20,67 \mathrm{de}$ & $28,33 \mathrm{fg}$ & $8,67 \mathrm{bc}$ & 16,00 & 20,33 & 170,00 \\
\hline k3p1 & 19,67 & $32,33 \mathrm{bc}$ & $42,33 \mathrm{ab}$ & $10,00 \mathrm{ab}$ & 17,00 & 20,67 & 168,33 \\
\hline $\mathrm{k} 3 \mathrm{p} 2$ & 20,33 & $33,00 \mathrm{abc}$ & $44,00 \mathrm{ab}$ & $10,67 \mathrm{ab}$ & 17,33 & 21,33 & 183,33 \\
\hline $\mathrm{k} 3 \mathrm{p} 3$ & 24,33 & $36,33 \mathrm{a}$ & $46,33 \mathrm{a}$ & $11,67 \mathrm{a}$ & 17,67 & 22,67 & 196,67 \\
\hline
\end{tabular}

Keterangan $:$ tn $=$ berpengaruh tidak, $*=$ berpengaruh nyata; $* *=$ berpengaruh sangat nyat;

HST $=$ hari setelah tanam

Angka rata-rata yang diikuti dengan huruf kecil yang sama adalah berbeda tidak nyata berdasarkan hasil uji BNT taraf $5 \%$

Hasil sidik ragam menunjukkan bahwa perlakuan pupuk Cantik berpengaruh nyata terhadap tinggi tanaman terong pada umur 15, 30, dan 45 hari setelah tanam. Hasil penelitian menunjukkan bahwa tinggi tanaman terong pada umur 15,30 , dan 45 hari setelah tanam semakin tinggi dengan pemberian berbagai dosis pupuk Cantik. Perlakuan 3,5 $\mathrm{g}^{\text {polibag }}{ }^{-1}$ (k3) menghasilkan tanaman terong ungu yang paling tinggi, yaitu berturut-turut $20,75 \mathrm{~cm}, 30,58 \mathrm{~cm}$, dan $38,08 \mathrm{~cm}$, sedangkan yang paling rendah dihasilkan pada perlakuan tanpa pupuk Cantik (k0), yaitu berturut-turut $14,58 \mathrm{~cm}, 27,83 \mathrm{~cm}$ dan $30,00 \mathrm{~cm}$. Hal ini disebabkan karena kandungan unsur hara dalam media tanam tergolong sangat rendah sampai rendah, khususnya $\mathrm{N}$ hanya sebesar $0,18 \%$ status tergolong rendah (Lampiran Tabel 8), sehingga dengan pemberian pupuk Cantik dapat meningkatkan unsur hara terutama unsur hara $\mathrm{N}$ yang sangat dibutuhkan tanaman untuk memacu pertumbuhan vegetative tanaman. Seperti dikemukakan oleh Prihmantoro (2006) bahwa unsur hara $\mathrm{N}$ diperlukan tanaman untuk pembentukan klorofil dan merangsang pertumbuhan vegetatif tanaman seperti batang, cabang dan daun.

Hasil sidik ragam menunjukkan bahwa pemberian pupuk Cantik berpengaruh nyata sampai sangat nyata terhadap jumlah buah per tanaman, diameter buah, panjang buah dan berat satu buah. Hasil penelitian menunjukkan 
bahwa pemberian berbagai dosis pupuk Cantik menghasilkan jumlah buah yang lebih banyak, diameter buah yang lebih besar, buah yang lebih panjang dan berat satu buah yang lebih besar dibandingkan dengan perlakuan tanpa pupuk Cantik (k0). Perlakuan pemberian 3,5 g polibag $^{-1}$ menghasilkan jumlah buah per tanaman yang paling banyak $(10,25$ buah), diameter buah yang paling besar $(17,00 \mathrm{~cm})$, panjang buah yang paling besar $(21,25 \mathrm{~cm})$ dan berat satu buah yang paling tinggi $\left(179,58 \mathrm{~g} \mathrm{buah}^{-1}\right)$. Hal ini disebabkan dengan pemberian pupuk Cantik dapat meningkatkan ketersediaan unsur hara N, P, dan K. Makin banyak unsur hara yang tersedia maka dapat meningkatkan serapan unsur hara oleh tanaman terong ungu, yang akhirnya dapat memberikan hasil buah yang lebih baik.

Pengaruh POC Hormonik terhadap Pertumbuhan dan Hasil Tanaman Terong Ungu. Hasil sidik ragam menunjukkan bahwa perlakuan pemberian POC Hormonik berpengaruh sangat nyata terhadap tinggi tanaman pada umur 15 , 30, dan 45 hari setelah tanam. Hasil penelitian menunjukkan bahwa pemberian berbagai konsentrasi POC Hormonik menghasilkan tanaman terong yang lebih tinggi pada umur 15, 30 dan 45 hari setelah tanam dibandingkan dengan perlakuan tanpa POC Hormonik. Tanaman terong yang paling tinggi dihasilka pada perlakuan $3 \mathrm{ml} \mathrm{l}^{-1}$ air (p3) yaitu berturut-turut $18,67 \mathrm{~cm}, 31,67 \mathrm{~cm}$, dan 38,08 cm; sedangkan yang paling rendah dihasilkan pada perlakuan tanpa POC Hormonik (p0) yaitu berturut-turut $14,67 \mathrm{~cm}, 20,93 \mathrm{~cm}$, dan $29,08 \mathrm{~cm}$. Hal ini disebabkan karena pemberian POC Hormonik dapat memenuhi kebutuhan unsur hara untuk pertumbuhan tanaman terong terutama unsur hara N. Seperti yang dinyatakan oleh Sarief (1986) bahwa unsur Nitrogen (N) sangat diperlukan tanaman untuk merangsang pertumbuhan vegetatif tanaman seperti batang, akar, daun dan cabang. Dengan tersedianya unsur hara $\mathrm{N}$ dapat memacu pertumbuhan tinggi tanaman terong.

Hasil sidik ragam menunjukkan bahwa perlakuan pemberian POC Hormonik berpengaruh sangat nyata terhadap jumlah buah per tanaman, berpengaruh tidak nyata terhadap diameter buah,dan panjang buah, dan berpengaruh nyata terhadap berat satu buah. Hasil penelitian menunjukkan bahwa pemberian berbagai konsentrasi POC Hormonik menghasilkan jumlah buah per tanaman yang lebih banyak, diameter buah yang lebih besar, buah yang lebih panjang dan berat satu buah yang lebih berat dibandingkan dengan perlakuan tanpa POC Hormonik. Hal ini disebabkan karena pemberian POC Hormonik dapat meningkatkan serapan unsur hara oleh tanaman terong, sehingga dapat memperbaiki kualitas buah yang dihasilkan. Seperti dinyatakan oleh Dwidjoseputro (1998), bahwa tanaman akan tumbuh subur dan memberikan hasil yang baik jika unsur hara yang dibutuhkannya tersedia dalam jumlah cukup dan seimbang.

Pengaruh Interaksi antara Pupuk Cantik dan POC Hormonik terhadap ertumbuhan dan Hasil Tanaman Terong Ungu. Hasil sidik ragam menunjukkan bahwa interaksi berpengaruh tidak nyata terhadap tinggi tanaman pada umur 15 hari setelah tanam, tetapi berpengaruh sangat nyata terhadap tinggi tanaman pada umur 30 dan 45 hari setelah tanam. Kemudian hasil sidik ragam menunjukkan bahwa interaksi berpengaruh nyata terhadap jumlah buah per tanaman, tetapi berpengaruh tidak nyata terhadap diameter buah, panjang buah dan berat satu buah. Seperti dikemukakan oleh Gomez dan Gomez (1995), bahwa dua faktor dikatakan berinteraksi apabila pengaruh suatu faktor perlakuan berubah pada saat perubahan 
taraf faktor perlakuan lainnya. Selanjutnya dinyatakan oleh Steel dan Torrie (1991), bahwa apabila pengaruh interaksi berbeda tidak nyata maka disimpulkan bahwa diantara faktor perlakuan tersebut bertindak bebas satu sama lainnya.

Secara umum hasil penelitian pada Tabel 9 menunjukkan bahwa pemberian kombinasi antara pupuk Cantuk dengan POC Hormonik menghasilkan pertumbuhan dan hasil buah tanaman terong ungu yang lebih baik dibandingkan dengan perlakuan kombinasi tanpa pupuk Cantik dan tanpa POC Hormonik.

\section{KESIMPULAN}

Berdasarkan hasil penelitian dan pembahasan dapat diambil kesimpulan yaitu sebagai berikut : Perlakuan pemberian pupuk Cantik berpengaruh sangat nyata terhadap tinggi tanaman pada umur 15, 30, dan 45 hari setelah tanam, jumlah buah per tanaman dan berat satu buah, dan berpengaruh nyata terhadap diameter dan panjang buah. Perlakuan 3,5 $\mathrm{g}_{\text {polibag }}{ }^{-1}$ menghasilkan hasil buah tanaman terong ungu yang paling baik.
Perlakuan pemberian POC Hormonik berpengaruh sangat nyata terhadap tinggi tanaman pada umur 15 , 30, dan 45 hari setelah tanam serta jumlah buah per tanaman; berpengaruh nyata terhadap berat satu buah, tetapi berpengaruh tidak nyata terhadap diameter buah dan panjang buah. Perlakuan $3 \mathrm{ml} \mathrm{l}^{-1}$ air menghasilkan hasil buah tanaman terong ungu yang paling baik.

Interaksi antara pupuk Cantik dan POC Hormonik berpengaruh sangat nyata terhadap tinggi tanaman pada umur 30 dan 45 hari setelah tanam; berpengaruh nyata terhadap jumlah buah per tanaman, tetapi berpengaruh tidak nyata terhadap tinggi tanaman pada umur 15 hari setelah tanam, diameter buah, panjang buah, dan berat satu buah.

\section{DAFTAR PUSTAKA}

Dwidjoseputro, D. (1998). Pengantar Fisiologi Tumbuhan. Jakarta: Gramedia.

Eriyandi. (2008). Budidaya Tanaman Terong. Bandung: Wahana Iptek. 
Gomez, K.A dan A.A. Gomez . (1995). Prosedur Statistik untuk Penelitian Pertanian (Terjemahan A. Sjamsuddin dan J.S Baharsyah). Jakarta: UI Press.

Harizamry. (2007). Gerbang Informasi Agrikultur Tanaman Terong Ungu (Solanum melongena L). Posted by Harizamry Under Agro-Jurnal Pertanian.

Musnandar, L.E. (2003). Pupuk Organik. Jakarta: Penebar Swadaya.
Prihmantoro, H. (2006). Memupuk Tanaman Sayuran. Jakarta: Penebar Swadaya.

Sarief, E.S. (1986). Kesuburan dan Pemupukan Tanah Pertanian. Bandung: Pustaka Buana.

Steel, R.G.D dan J. H. Torrie. (1991). Prinsip dan Prosedur Statistika Suatu Pendekatan Biometrik. Jakarta: Gramedia Pustaka Utama. 